Chirurgia (2019) 114: 89-94

No. 1, January - February

Copyright $@$ Celsius

http://dx.doi.org/10.21614/chirurgia.114.1.89

\title{
Effect of Genetic Factors on the Etiopathogenesis of Thrombosed Hemorrhoidal Disease
}

\author{
Haci Hasan Abuoğlu, Emre Gunay, Hakan Uzunoğlu \\ General Surgery, Haydarpasa Numune Training and Research Hospital, Uskudar, Istanbul, Turkey
}

Corresponding author:

Haci Hasan Abuoglu, MD

19 Mayis Cod. Simpas. Central life

Monolya D/17, 34773, Umraniye

Istanbul, Turkey

E-mail: abuoglu@yahoo.com

\section{Rezumat \\ Efectul factorilor genetici în etiopatogenia trombozei hemoroidale}

Obiectiv: Scopul acestui studiu este de a investiga dacã factorii genetici care cresc riscul trombotic, joacã de asemenea un rol în etiopatogenia bolii hemoroidale trombotice (BHT).

Metode: Prezența eventualelor mutații ale factorului V Leiden, protrombinei G20210A, metilentetrahidrofolat reductazei C677T, şi respectiv metilentetrahidrofolat reductazei A1298C a fost testatã în materialul genomic prelevat de la pacienți cu boala hemoroidalã trombozatã.

Rezultate: $\mathrm{Nu}$ au fost depistate diferențe semnificative din punct de vedere statistic în ceea ce priveşte frecvența allelelor mutante la nivelul genelor menționate precedent $(\mathrm{p}>0.05)$. Mai mult decât atât, $\mathrm{nu}$ au fost decelate diferențe semnicative statistic din punct de vedere al genotipului (mutații hetero- sau homozigote) factorului $\mathrm{V}$ Leiden, protrombinei G20210A, metilentetrahidrofolat reductazei C677T şi respectiv A1298C între pacienți cu BHT şi grupul de control ( $>0.05)$.

Concluzii: Studiul nostru indicã faptul cã mutatiile asociate cu tromboembolismul venos nu par sã joace un rol în etiopatogenia BHT. Cu toate acestea, multipli factori mecanici, hemodinamici cât şi cei care țin de interacțiunea cu mediul înconjurãtor pot contribui la etiopatogenia bolii hemoroidale.

Cuvinte cheie: hemoroizi, genetic umanã, factor V Leiden, protrombinã, protein umanã MTHFR, mutație 


\section{Abstract}

Objective: The aim of this study is to investigate whether genetic factors known to increase thrombosis risk play a role in the etiopathogenesis of thrombosed hemorrhoidal disease.

Methods: Genomic DNA from patients with thrombosed hemorrhoidal disease was analyzed for the presence of factor V Leiden, prothrombin G20210A, methylenetetrahydrofolate reductase C677T, and methylenetetrahydrofolate reductase A1298C mutations.

Results: No significant differences were found in the allele frequencies of factor V Leiden, prothrombin G20210A, methylenetetrahydrofolate reductase C677T, and methylenetetrahydrofolate reductase A1298C mutations between patients with thrombosed hemorrhoidal disease and controls $(\mathrm{p}>0.05)$. Moreover, there were no significant differences in the genotype (heterozygous and homozygous mutations) of factor V Leiden, prothrombin G20210A, methylenetetrahydrofolate reductase $\mathrm{C} 677 \mathrm{~T}$ and $\mathrm{A} 1298 \mathrm{C}$ mutations between patients with thrombosed hemorrhoidal disease and controls $(\mathrm{p}>0.05)$.

Conclusions: Our findings indicate that mutations associated with venous thromboembolism do not play a role in the etiopathogenesis of thrombosed hemorrhoidal disease; however, several environmental, mechanical, and hemodynamic factors may contribute to the etiopathogenesis of hemorrhoidal disease.

Key words: hemorrhoids, human genetics, factor V Leiden, prothrombin, MTHFR protein, human, mutation

\section{Introduction}

Hemorrhoids are very common disease of the anorectal region. They are defined as symptomatic growth and / or distal displacement of anal cushions $(1,2)$. The anal cushions are formed by loose connective tissue, smooth muscle, arterial and venous vessels (3). Hemorrhoidal disease is very common in the Western world, England and the United States (4-6).

Hyperhomocysteinemia, a disorder of methionine metabolism, is suggested to represent a modifiable risk factor for myocardial infarction, peripheral arterial thrombosis, deep vein thrombosis, and pulmonary embolism (7). A large number of previous studies have linked arterial disease to an increased homocysteine level; in addition, a few controversial studies have suggested a relationship between homo-cysteine levels and venous thrombosis (8). It has been reported that hyperhomocysteinemia represents a risk factor for venous thrombosis. Although the link between hyperhomocysteinemia and venous thrombosis is still debated (9), several case-control studies and meta-analyses have shown that the prevalence of homocysteinemia is higher in patients with venous thrombosis (10). Mild-to-moderate hyperhomocysteinemia may result from relative deficiencies of folic acid and vitamin B12 and homozygosity for the common polymorphism in the methylenetetrahydrofolate reductase (MTHFR) C677T gene (11). Increased homocysteine levels exert toxic effects on vascular structures (12). Therefore, hyperhomocysteinemia has been associated with numerous disorders such as cardiovascular disease, stroke, and venous thrombosis. The MTHFR C677T polymorphism is the most commonly encountered genetic anomaly related to hyperhomocysteinemia. This polymorphism is linked to reduced enzyme levels and an associated increase in homocysteine levels (13). The association of the MTHFR C677T polymorphism with folate levels is controversial (14). Li et al. demonstrated that heterozygous and homo-zygous MTHFR A1298C mutations were associated with higher folate levels, suggesting that the MTHFR may represent a protective factor that reduces the risk of folate deficiency (15). 
Genetic factors result in a hereditary predisposition to venous thromboembolism (16). In addition, hyperhomocysteinemia represents a risk factor for thrombosis. Folic acid deficiency may lead to increased serum levels of homocysteine. A mutation in the MTHFR gene causes folic acid deficiency, which in turn leads to an increased risk of hyperhomocysteinemia and thrombosis (17). Prothrombin, a serine protease thrombin precursor, is a key enzyme in hemostasis. The heterozygous state of a single guanine for adenine substitution at nucleotide 20,210 of the prothrombin-encoding gene that is not subjected to 3 ' translation (20210A) (factor II; FII) is a risk factor for thrombosis (18). A mutation in the factor $\mathrm{V}$ Leiden gene that involves a guanine to adenine nucleotide change results in the resistance of Factor $\mathrm{V}$ to inactivation by Protein C, leading to a procoagulant state $(19,20)$.

According to the widely accepted theory, If the supporting tissues of the anal cushions are damaged, they cause hemorrhoids (21). Hemorrhoids develop as a result of abnormally downward displacement of anal cushions, which causes venous dilatation. In hemorrhoid patients, the anal cushions show important pathological changes, for instance abnormal venous dilatation, vascular thrombosis, distortion and rupture of the anal subepithelial muscle. In addition to the examples, a severe inflammatory reaction involving the vascular wall and surrounding connective tissue was demonstrated in hemorrhoidal specimens (22).

Other contributors to the etiopathology of hemorrhoids include genetic factors and venous dilatation and distention (23). One or more of the above mentioned mechanisms, in combination with predisposing genetic factors, may play a role in the etiopathogenesis of the disease.

In this study, we aimed to investigate the frequency of overall mutations and the frequency of heterozygous vs. homozygous alleles independently, and to assess the role of these genetic factors in the etiopathogenesis of thrombosed hemorrhoidal disease.

\section{Methods}

Our study group included 125 patients aged between 29 and 65 years (mean age: $41.12 \pm$ 8.12 years) who underwent colonoscopic examination in 2014 and were diagnosed with thrombosed hemorrhoidal disease (thrombosed grade IV internal hemorrhoids and thrombosed external hemorrhoids). Patients who were pregnant were excluded from the study. Controls were selected from the general population. Individuals with a history of thrombosis or vascular disorders, as well as those with family history of such disorders, were excluded from the control group. The study received approval from the local ethics committee of Haydarpaşa Numune Training and Research Hospital and conformed with the declaration of Helsinki. We declared that written informed consent was obtained from all patients who were enrolled in this study.

Blood samples were drawn from patients into EDTA-containing tubes. Genomic DNA was extracted from leukocytes using a Magrev ${ }^{\circledR} 24$ Manual Magnetic Bead Nucleic Acid Extraction Standfor 24 Samples \& PCR Setup Robot and Magrev ${ }^{\circledR}$ DNA Blood Mini Kit (AEDAA00044) (Anatolia Geneworks).

Genomic DNA was analyzed for the presence of factor $\mathrm{V}$ Leiden, prothrombin G20210A, MTHFR C677T, and MTHFR A1298C mutations using Bosphore Kits and Real-Time PCR (Montania 483 Anatolia, Turkey). Our control group included 197 individuals without hemorrhoidal disease, who did not have any of the above mentioned mutations.

We used the following commercial kits: Bosphore Prothrombin Detection Kit v1, Bosphore FVL Detection Kit v1, Bosphore MTHFR C677T Detection Kit v1 and Bosphore MTHFR A1298C Detection Kit v1 (Anatolia Geneworks, Turkey); these kits employ Real-Time PCR method based on dual labeled hydrolysis probes to achieve allelic discrimination.

FAM and HEX fluorescent dyes were used for detection of the mutant and wild type alleles respectively, using the Montania 4896 
Real-Time PCR Instrument (Anatolia Geneworks, Turkey). The thermal protocols were applied according to the instructions of the kit manufacturer. Thermal protocol was the same for all the kits except Bosphore MTHFR A1298C Detection Kit v1: an initial denaturation of $95^{\circ} \mathrm{C}$ for $14: 30$ minutes, followed by 35 cycles of; denaturation at $95^{\circ} \mathrm{C}$ for 30 seconds, annealing and synthesis/ fluorescent data collection step at $64^{\circ} \mathrm{C}$ for 30 seconds, followed by a final hold at $22^{\circ} \mathrm{C}$ for 5 minutes. For the MTHFR A1298C Detection Kit v1, the thermal protocol was follows: an initial denaturation of $95^{\circ} \mathrm{C}$ for $14: 30$ minutes, followed by 35 cycles of; denaturation at $95^{\circ} \mathrm{C}$ for 30 seconds, annealing and synthesis/ fluorescent data collection step at $60^{\circ} \mathrm{C}$ for 30 seconds, followedby a final hold at $22^{\circ} \mathrm{C}$ for 5 minutes.

Factor V Leiden mutations were analyzed by Real-Time PCR using the Bosphore ${ }^{\circledR}$ FVL Detection Kit v1 (FVLHA000229) (Anatolia Geneworks $\left.{ }^{\circledR}\right)$, which detects theG1691A mutation in theF5 gene by using dual-labeled fluorescent hydrolysis probes.

The prothrombin G20210A mutation was detected in theFII gene by Real-Time PCR using the Bosphore ${ }^{\circledR}$ Prothrombin Detection Kit v1 (PROHA000201) (AnatoliaGeneworks®) withdual-labeled fluorescent hydrolysis probes.

The MTHFR C677T mutation was detected by Real-Time PCR using the Bosphore ${ }^{\circledR}$ MTHFRC677T Detection Kit v1 (677HA000248) (Anatolia Geneworks ${ }^{\circledR}$ ) with dual-labeled fluorescent hydrolysis probes.

The MTHFR A1298C mutation was detected by Real-Time PCR using the Bosphore ${ }^{\circledR} \mathrm{MTH}^{-}$ FRA1298C Detection Kit v1 (129HA000179)
(Anatolia Geneworks®) with dual-labeled fluorescent hydrolysis probes.

Montania ${ }^{\circledR} 4896$ (Anatolia Geneworks ${ }^{\circledR}$ ) was used as the Real-Time PCR instrument.

Statistical analyses were performed using the SHEsis (24) software package. The heterozygous and homozygous genotype frequencies were determined for the factor V Leiden, prothrombin G20210A (FII), MTHFR C677T, and MTHFR A1298C mutations. Chi-Square test was used for inter-group comparisons. A p value of less than 0.05 was considered to represent statistical significance.

\section{Results}

The distribution of allele frequencies for the factor V Leiden, prothrombin G20210A (FII), MTHFR C677T, and MTHFR A1298C mutations in patients with thrombosed hemorrhoidal disease is shown in Table 1. There were no significant differences in the allele frequencies of factor $\mathrm{V}$ Leiden, prothrombin G20210A (FII), MTHFR C677T, and MTHFR A1298C mutations between patients with thrombosed hemorrhoidal disease and controls $(\mathrm{p}>0.05)$.

Table 2 shows the distribution of patients with thrombosed hemorrhoidal disease that were heterozygous or homozygous for factor $\mathrm{V}$ Leiden, prothrombin G20210A (FII), MTHFR C677T, and MTHFR A1298C mutations. No significant difference was found between patients with thrombosed hemorrhoidal disease and controls with respect to factor $\mathrm{V}$ Leiden, prothrombin G20210A (FII), and MTHFR C677T heterozygous and homozygous mutations ( $p>0.05$ ).

Table 1. Distribution of allele frequencies for factor V Leiden (FVL), prothrombin G20210A (FII), MTHFR C677T, and MTHFR A1298C mutations in patients with thrombosed hemorrhoidal disease

\begin{tabular}{lccccc}
\hline Allele & Patient & \multicolumn{3}{c}{ Control } & p value \\
\hline & Normal & Mutant & Normal & Mutant & \\
\hline FVL & $241(96 \%)$ & $9(4 \%)$ & $388(98 \%)$ & $6(2 \%)$ & 0.088597 \\
\hline FII & $250(100 \%)$ & $0(0 \%)$ & $391(99 \%)$ & $3(1 \%)$ & 0.166752 \\
\hline MTHFR C677T & $189(76 \%)$ & $61(24 \%)$ & $313(79 \%)$ & $81(21 \%)$ & 0.251855 \\
\hline MTHFR A1298C & $155(62 \%)$ & $95(38 \%)$ & $263(67 \%)$ & $131(33 \%)$ & 0.218306 \\
\hline
\end{tabular}

$p<0.05$ was considered to represent statistical significance 
Table 2. Distribution of the genotype of patients with thrombosed hemorrhoidal diseasewhowere heterozygous or homozygous for factor V Leiden (FVL), prothrombin G20210A (FII), MTHFR C677T, and MTHFR A1298C mutations

\begin{tabular}{lccccccc}
\hline Genotype & Patient & & & Control & & p value \\
\hline FVL & Normal & Heterozygous & Homozygous & Normal & Heterozygous & Homozygous \\
\hline FII & $116(93 \%)$ & $9(7 \%)$ & $0(0 \%)$ & $191(97 \%)$ & $6(3 \%)$ & $0(0 \%)$ & 0.084796 \\
\hline MTHFR C677T & $125(10 \% \%)$ & $0(0 \%)$ & $0(0 \%)$ & $194(99 \%)$ & $3(1 \%)$ & $0(0 \%)$ & 0.165758 \\
\hline MTHFR A1298C & $68(54 \%)$ & $53(43 \%)$ & $4(3 \%)$ & $121(61 \%)$ & $71(36 \%)$ & $5(3 \%)$ & 0.457241 \\
\hline
\end{tabular}

$\mathrm{p}<0.05$ was considered to represent statistical significance

\section{Discussion}

The roles of factor V Leiden, FII, and MTHFR gene mutations in deep vein thrombosis, pulmonary embolism, cerebrovascular events, and similar thromboembolisms are well established. However, to our knowledge, there are no studies supporting the role of thrombosis and embolism in the pathogenesis of hemorrhoidal disease. The present study was performed to examine whether genetic risk factors for thrombophilia are linked with the etiopathology of hemorrhoidal disease.

In our study, the difference in allele frequencies of MTHFR C677T and MTHFR A1298C mutations between patients and controls were not statistically significant ( $>0.05)$. We hypothesized that, despite the lack of statistically significant differences in terms of allele frequency, differences between patients and controls may be observed based on their genotype; therefore, we additionally compared the two groups based on homozygosity and heterozygosity. No significant differences between the patients and healthy controls were observed with regard to heterozygous and homozygous MTHFR C677T mutations $(p>0.05)$. Our data indicate that the MTHFR C677T mutation, which is associated with an increased risk of venous thrombosis, was not linked with the development of thrombosed hemorrhoidal disease in the population studied. Factor V Leiden and prothrombin gene heterozygosity, which result in systemic hypercoagulability, represent major risk factors for venous thrombosis. Factor V Leiden mutation is associated with resistance of factor $\mathrm{V}$ to inactivation by protein $\mathrm{C}$, leading to a procoagulant state $(19,20) ; 5 \%$ of the Caucasian race harbor are heterozygous for the Factor $\mathrm{V}$ Leiden mutation (25). We found that the allele frequency of this mutation did not differ significantly between the patient and control groups $(p>0.05)$. In addition, no significant differences were observed between the two groups in terms of heterozygosity or homozygosity for Factor V Leiden mutations ( $p>$ 0.05). Our data indicate that the Factor $\mathrm{V}$ Leiden mutation, which is associated with an increased risk of venous thrombosis, was not linked with the development of thrombosed hemorrhoidal disease in the population studied. The prothrombin gene mutation involves a guanine to adenine change in the 20,210th nucleotide of the FII gene, resulting in a procoagulant state that is associated with higher plasma prothrombin levels (26). The prothrombin gene mutation is similar to the Factor V Leiden mutation in that it is frequently observed in the Caucasian race (prevalence range: $1-4 \%$ ) (27) and associated with thromboembolism (28-30). In the present study, there was no significant difference between the patient population and the healthy control population with respect to the frequency of this allele $(p>0.05)$. Furthermore, there were no significant differences between the patients and healthy controls with regard to heterozygosity and homozygosity for this mutation $(p>0.05)$. Our data indicate that the prothrombin gene mutation was not linked with the development of thrombosed hemorrhoidal disease in the population studied.

Taken together, our findings indicate that the mutations in the four genes studied are not implicated in the etiopathogenesis of throm- 
bosed hemorrhoidal disease. We suggest that other environmental, mechanical, and hemodynamic factors, such as nutritional and defecation habits, working environment, and other behaviors, may contribute to the etiopathogenesis of hemorrhoidal disease. As hemorrhoidal disease is a vascular disorder, thromboembolism may additionally contribute to the abovementioned factors.

\section{Conflicts of Interest: None declared.}

Funding support: Our study wasn't funded.

\section{References}

1. Lohsiriwat V. Approach to hemorrhoids. CurrGastroenterol Rep 2013:15:332

2. Lohsiriwat V. Hemorrhoids: from basic pathophysiology to clinical management. World J Gastroenterol 2012;18:2009-2017.

3. Thomson WH. The nature and cause of haemorrhoids. Proc R Soc Med 1975;68:574-575.

4. Abcarian $\mathrm{H}$, Alexander-Williams J, Christiansen J, Johanson J, Killingback M, Nelson RL, et al. Benign anorectal disease: definition, characterization and analysis of treatment. Am J Gastroenterol 1994;89:S182-S193.

5. Johanson JF, Sonnenberg A. The prevalence of hemorrhoids and chronic constipation. An epidemiologic study. Gastroenterology 1990:98:380-386

6. Kaidar-Person 0, Person B, Wexner SD. Hemorrhoidal disease: a comprehensive review. J Am CollSurg 2007;204:102-117.

7. Ravari H, Zafarghandi MR, Alvandfar D, Saadat S. Serum homocysteine in deep venous thrombosis, peripheral atherosclerosis \& healthy Iranians: a case-control study. Pak J BiolSci 2009; 12:1019-1024.

8. Clarke R. Lowering blood homocysteine with folic acid based supplements: meta-analysis of randomized trials. BMJ 1998; 316:894-898.

9. Ducros V, Barro C, Yver J, Pernod G, Polack B, Carpentier P. Should plasma homocysteine be used as a biomarker of venous thromboembolism? A case-control study. Clin Appl Thromb Hemos. 2009; 15:571-522.

10. Hainaut $P$, Jaumotte $C$, Verhelst D, Wallemacq $P$, Gala Jean-Lu, Lavenne E. Hyperhomocysteinemia\& venous thromboembolism: a risk factor more prevalent in the elderly and in idiopathic cases. Thromb Res 2002;106:121-125.

11. Hanta I, Soydas Y, Karatasli M, Koseoglu S, Satar S, Hasturk S Plasma homocysteine level \& 677C-T mutation on the MTHFR gene in patients with venous thromboembolism. Bratisl Lak Listy 2010; 111:70-73.

12. Undas A, Domagala TB, Jankowski M, Szczeklik A. Treatment of hyperhomocysteinemia with folic acid \& vitamins B12 \& B6 attenuates thrombin generation. Thromb Res 1999;95:281-288

13. Kokturk N, Kanbay A, Aydogdu M, Ozyılmaz E, Bukan N, Ekim N. Hyperhomocysteinemia prevalence among patients with venous thromboembolism. ClinApplThrombHemos 2011:17:487-493.

14. Biselli PM, Guerzoni, AR, de Godoy MF, Eberlin MN, Haddad R, Carvalho VM, et al. Genetic polymorphisms involved in folate metabolism and concentrations of methylmalonic acid and folate on plasma homocysteine and risk of coronary artery disease. J Thromb Thrombolysis 2010;29:32-40.

15. Li WX, Dai SX, Zheng JJ, Liu JQ, Huang JF. Homocysteine metabolism gene polymorphisms (MTHFR C677T, MTHFR A1298C, MTR A2756G and MTRR A66G) jointly elevate the risk of folatedeficiency. Nutrients. 2015;7:6670-6687.

16. Luxembourg B, Delev D, Geisen C, Spannagl M, Krause M, Miesbach W, et al. Molecular basis of antithrombin deficiency. Thromb Haemost 2011;105:635-646.

17. Ekim M, Ekim H, Yilmaz YK, Kulah B, Polat MF, Gocmen AY. Study on relationships among deep vein thrombosis, homocysteine\& related B group vitamins. Pak J Med Sci 2015;31(2):398-402.

18. Kellett MW, Martin PJ, Enevoldson TP, Brammer C, Toh C. Cerebral venous sinus thrombosis associated with 20210A mutation of the prothrombin gene. J Neurol Neurosurg Psychiatry 1998;65: 611-612.

19. Ben-Ami R, Zeltser D, Leibowitz I, Berliner SA. Retinal artery occlu $\neg$ sion in a patient with factor $V$ Leiden and prothrombin G20210A mutations. Blood Coagul Fibrinolysis 2002;13:57-59.

20. Bertina RM, Koeleman BP, Koster T, Rosendaal FR, Dirven RJ, de RondeH,et al. Mutation in blood coagulation factor $\mathrm{V}$ associated with resistance to activated protein C. Nature 1994;369:64-67.

21. Thomson WH. The nature of haemorrhoids. Br J Surg 1975; 62:542-552.

22. Morgado PJ, Suárez JA, Gómez LG, Morgado PJ. Histoclinical basis for a new classification of hemorrhoidal disease. Dis Colon Rectum 1988; 31:474-480.

23. Sanchez C, Chin B. Hemorrhoids. Clin Colon Rectal Surg 2011; 24:1-13.

24. Shi YY, He L. SHEsis, a powerful software platform for analyses of linkage disequilibrium, haplotype construction, and genetic association at polymorphism loci. Cell Res 2005:15:97-98.

25. Ridker PM, Miletich JP, Hennekens CH, Buring JE. Ethnic distribution of factor $\mathrm{V}$ Leiden in 4047 men and women. Implications for venous thromboembolism screening. JAMA 1997:277:1305-1307.

26. Poort SR, Rosendaal FR, Reitsma PH, Bertina RM. A common genetic variation in the 3 -untranslated region of the prothrombin gene is associated with elevated plasma prothrombin levels and an increase in venous thrombosis. Blood 1996;88:3698-3703.

27. Rosendaal FR, Doggen CJ, Zivelin A, Arruda VR, Aiach M, Siscovick DS, et al. Geographic distribution of the $20210 \mathrm{G}$ to A prothrombin variant. Thromb Haemost 1998;79:706-708.

28. Simsek E, Yesilyurt A, Pinarli F, Eyerci N, Ulus AT. Combined genetic mutations have remarkable effect on deep venous thrombosis and/or pulmonary embolism occurrence. Gene 2013;536:171-6.

29. Zhou X, Qian W, Li J, Zhang P, Yang Z, Chen W,et al. Who are at risk for thromboembolism after arthroplasty? A systematic review and meta-analysis. Thromb Res 2013;132:531-536.

30. Tug E, Aydin H, Kaplan E, Dogruer D. Frequency of genetic mutations associated with thromboembolism in the Western Black Sea Region. Intern Med 2011;50:17-21. 